\title{
Biogeographic differences in claw size and performance in an introduced crab predator Carcinus maenas
}

\author{
L. David Smith* \\ Department of Biological Sciences and Environmental Science and Policy Program, 235 Sabin-Reed Hall, Smith College, \\ Northampton, Massachusetts 01063, USA
}

\begin{abstract}
Introduced predators must forage effectively to persist in new areas, and effective resource use is correlated with a predator's trophic (feeding) structures. The extent to which trophic morphology responds to spatial variation in prey resistance, and the time scale of that response, however, are not well understood. The introduced European green crab Carcinus maenas, which has expanded its range in the northwest Atlantic Ocean over the last century and encountered a latitudinal cline in prey armor, offers an ideal opportunity to test for such post-invasion changes. In rocky intertidal habitats in the Gulf of Maine, southern populations of the snail Littorina obtusata are better defended than northern populations. To test for correlated differences in claw size and prey defense, green crabs and common molluscan prey were collected at southern and northern sites in the Gulf of Maine. C. maenas are heterochelous, and analyses revealed that crusher claws of crabs collected in the south were significantly larger than those of crabs from the north after adjusting for carapace width. The size of the cutter claw, however, did not differ between regions. Shell weights for similarsized snails differed among sites for 3 of the 4 species examined, but did not differ by region. To test crushing performance, southern and northern crabs were presented with increasing sizes of southern or northern L. obtusata in the laboratory. For similar-sized individuals, southern crabs were able to crush significantly larger snails than northern crabs regardless of the geographic origin of the snails. Thus, patterns in claw size and performance strongly suggest trophic responses to geographic differences in prey armor. Rapid changes in trophic morphology could facilitate the spread of this invasive species and initiate an ecological arms race if both predator and prey respond ecophenotypically to each other.
\end{abstract}

KEY WORDS: Introduced species · Trophic polymorphism $\cdot$ Crab claws $\cdot$ Phenotypic plasticity $\cdot$ Rapid evolution $\cdot$ Ecological arms race $\cdot$ Carcinus maenas $\cdot$ Littorina obtusata

\section{INTRODUCTION}

Ecological research on marine biological invasions has focused primarily on assessing the impacts (e.g. habitat alteration, competitive displacement, predation) of introduced species on resident populations or communities (Brenchley \& Carlton 1983, Crooks 1998, Grosholz et al. 2000). Substantially less is known about how introduced species respond ecologically or evolutionarily to their new environment, particularly over broader spatial scales or longer time frames (Carroll \&
Dingle 1996, Vermeij 1996). For example, as an introduced species spreads along a coastline, it may encounter different prey defenses, habitat types or temperature regimes. The extent to which the invader can respond adaptively to such environmental variation and the rapidity of that response will influence its long-term viability and rate of range expansion.

To establish and spread, an introduced predator must forage successfully on local prey. Over time, traits that influence a predator's foraging success may vary geographically depending on the distribution and abun- 
dance of well-defended prey (Vermeij 1978, Brodie \& Brodie 1991). Tests for adaptive responses in introduced (and native) predator populations are lacking in part, because selective pressures are presumed to be lower for predators (a lost meal) than for their prey (a lost life) (Dawkins \& Krebs 1979, Brodie \& Brodie 1999, Abrams 2000). Predators, however, must contend with their own constraints (Huey \& Pianka 1981, Lima \& Dill 1990), and their fitness is integrally tied to effective resource use (Boag \& Grant 1981, Pyke 1984).

Effective resource utilization depends to a great extent on a predator's feeding morphology (Wainwright 1994), and diet-related trophic polymorphisms exist in many species (Skúlason \& Smith 1995, Smith \& Skúlason 1996). For example, pumpkinseed sunfish in a lake with abundant gastropod prey consumed more snails and had significantly larger jaw musculature than did sunfish in a lake with few snails (Wainwright et al. 1991). In some cases, trophic morphology is under strong genetic control and geographic differences reflect local adaptation to prey (Carroll \& Dingle 1996). In others, trophic variation results from diet-induced phenotypic plasticity, as seen in many taxonomic groups, including ciliates (Kopp \& Tollrian 2003), crustaceans (Smith \& Palmer 1994), insects (Bernays 1986), molluscs (Padilla 1998, Reid \& Mak 1999), echinoderms (Hart \& Strathmann 1994), fishes (Wimberger 1991, Day et al. 1994, Mittelbach et al. 1999) and amphibians (Walls et al. 1993, Pfennig \& Murphy 2002). Broad-ranging invasive species may be those capable of modifying their feeding apparatus quickly by either mechanism to overcome prey resistance.

Molluscivorous crabs are good candidates to test for post-invasion changes in trophic morphology for a number of reasons. First, they are ecologically important predators that use specialized trophic structures (claws) to break through the defensive armor of their prey. Second, biogeographic and fossil evidence indicate that improvements in claw design have been matched over evolutionary time by increased shell defenses in molluscs (Vermeij 1978, West et al. 1991). Third, shell-breaking ability is directly correlated to claw closing force, which varies among species as a function of the size, leverage properties and dentition of the claw, and the type and angle of pinnation of the claw's closer muscle fibers (e.g. Warner \& Jones 1976, Elner 1978, Seed \& Hughes 1995, Behrens Yamada \& Boulding 1998, Schenk \& Wainwright 2001). Because many of these biomechanical properties show little variation within species, claw size becomes the chief morphological determinant of crushing ability (Elner 1980, Lee 1993, Taylor 2000) and crabs with relatively larger claws have a foraging advantage over those with smaller claws. Fourth, claw size and strength are developmentally sensitive to diet (Smith \& Palmer
1994), which opens the possibility for withingeneration trophic responses by crabs to temporal or spatial differences in prey defenses. Finally, molluscivorous crabs have invaded the margins of many continents (Lemaitre 1995, Grosholz \& Ruiz 1996). As these species expand their ranges, populations confronted with better armored prey may develop relatively larger and stronger claws than those faced with less resistant prey.

During the last 2 centuries, the European green crab Carcinus maenas (family Portunidae) has invaded sites in Japan, South Africa, Australia, and both Atlantic and Pacific coasts of the United States (Cohen et al. 1995, Grosholz \& Ruiz 1996, Geller et al. 1997). C. maenas is an omnivore that can be found intertidally and subtidally on both hard- and soft-bottom substrata (Behrens Yamada 2001). As it grows, the composition of its diet shifts from primarily plants and soft-shelled prey to mainly hard-shelled bivalves and gastropods (Ropes 1968, Elner 1981). The evolutionary importance of molluscivory for C. maenas is illustrated by the specialization of its claws into a larger, more powerful crusher claw for breaking shells and a smaller, weaker cutter claw for manipulating food (Warner et al. 1982, Seed \& Hughes 1995, Preston et al. 1996). If diet influences claw size and performance within or between generations, one would expect to observe the following in the trophic structure of $C$. maenas: (1) differences that correlate positively with spatial or temporal variation in prey armor; (2) greater modifications of the crusher than of the cutter claw; (3) differences affecting both sexes, because their diets differ little.

An opportunity to test these hypotheses exists in the northwest Atlantic Ocean, where Carcinus maenas has expanded its range over the last century and encountered a latitudinal cline in prey armor. Introduced originally to the mid-Atlantic coast of North America from Europe in the early 1800s, the green crab expanded north of Cape Cod, Massachusetts into the Gulf of Maine around 1900 and had reached its present northern extent in the Canadian Maritime provinces by the early 1950s (Scattergood 1952, Welch 1968). Predation by the green crab probably caused 2 species of intertidal snails (Littorina obtusata, Nucella lapillus) in the Gulf of Maine to shift to better-defended shell morphologies (Vermeij 1982a,b, Seeley 1986). At present, southern populations of L. obtusata in the Gulf of Maine possess significantly thicker shell walls than their northern counterparts (Seeley 1986, Trussell 1996, 2000). These geographic differences may reflect greater predation pressure on snails in the south where C. maenas are more abundant, and higher energetic costs of shell deposition in the north where summertime temperatures are colder (Trussell \& Smith 
2000). If trophic morphology correlates to geographic patterns in breakage resistance of available prey, then green crab populations from the southern Gulf of Maine should have relatively larger and stronger claws than those from the north. The present study tested for such a spatial pattern in both claw size and performance of C. maenas and in shell thickness of all locally abundant molluscan prey.

\section{MATERIALS AND METHODS}

Study sites and collection methods. To test for geographic differences in claw morphology and prey shell defenses in the Gulf of Maine, individual Carcinus maenas and molluscs were collected from the low-tomid intertidal zone at each of 3 rocky sites in Massachusetts and 3 in Maine in September and October 1997. Sites in Massachusetts (henceforth, 'the southern region') extended over a linear distance of approximately $34 \mathrm{~km}$; from south to north they were: Dive Beach, Nahant $\left(42^{\circ} 25^{\prime} 11^{\prime \prime} \mathrm{N}, 70^{\circ} 54^{\prime} 11^{\prime \prime} \mathrm{W}\right)$; White Beach, Manchester-by-the-Sea $\left(42^{\circ} 34^{\prime} 36^{\prime \prime} \mathrm{N}, 70^{\circ} 44^{\prime}\right.$ $\left.15^{\prime \prime} \mathrm{W}\right) ;$ and Back Beach, Rockport $\left(42^{\circ} 39^{\prime} 39^{\prime \prime} \mathrm{N}\right.$, $70^{\circ} 37^{\prime} 22^{\prime \prime} \mathrm{W}$ ). Sites in northern Maine (henceforth, 'the northern region') extended over a linear distance of approximately $24 \mathrm{~km}$; from south to north they were:

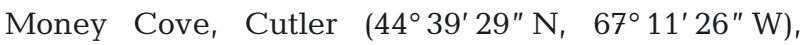
Haycock Harbor, South Trescott $\left(44^{\circ} 45^{\prime} 12^{\prime \prime}\right.$ N, 67 $03^{\circ}$ $\left.47^{\prime \prime} \mathrm{W}\right)$, and Carrying Place Cove, South Lubec $\left(44^{\circ}\right.$ $\left.48^{\prime} 25^{\prime \prime} \mathrm{N}, 66^{\circ} 58^{\prime} 51^{\prime \prime} \mathrm{W}\right)$. All collection sites were in moderately wave-protected embayments along the outer coast. The substrata consisted of a mixture of rocks and boulders that were resting on a sand substratum and covered by brown algae (species of Fucus and Ascophyllum).

At each site, approximately 30 male and 30 female Carcinus maenas were collected by hand after turning over rocks. Individuals with both chelipeds intact were chosen, which represented the available size range. A size range of approximately 30 individuals of each species of mollusc commonly encountered at each site was collected, including the limpet Tectura testudinalis, dogwhelk Nucella lapillus, and periwinkles Littorina littorea and L. obtusata. Within 24 to $48 \mathrm{~h}$ of collection, crabs and snails were sacrificed by freezing.

Morphometric analyses. For each crab, the carapace width (CW) was measured using digital calipers $( \pm 0.01 \mathrm{~mm})$. To facilitate claw measurements, both chelipeds from each crab were severed between the meral and carpal segments. Each claw was then positioned in a bowl filled with sand so that the claw's inner face was embedded in the sand. The outline of the outer face of each claw perpendicular to the plane of movement of the dactyl was drawn using a camera lucida fitted to a Leica MZ8 dissecting stereomicroscope with a $0.3 \times$-reducing lens. A $10 \mathrm{~mm}$ scale bar was included in each drawing. The average propus length (mean $\pm 1 \mathrm{SD}$ ) of the drawings was $124 \pm$ $18.8 \mathrm{~mm}(\mathrm{n}=294)$. The $x, y$ coordinates of claw landmarks were digitized on a Summasketch III drawing tablet (100 lines $\mathrm{mm}^{-1}$ resolution). Calibrated distances (mm) were computed between landmarks using MacMeasure (Version 1.9; A. R. Palmer, University of Alberta). The length of the manus (the portion of the claw excluding the fingers) was defined as the distance from the midpoint of the line between the upper and lower condyle sockets at the proximal end of the manus to the intersection of the ventral margin of the dactyl with the manus, when the dactyl was 50 to $75 \%$ open (equivalent to the point of insertion of the closer apodeme on the dactyl) (Fig. 1). Manus height was calculated as the distance between the upper and lower margins at the midpoint of the manus length. Manus depth was the dimension of the manus perpendicular to the drawing at the midpoint of the manus (measured to $0.01 \mathrm{~mm}$ with digital calipers).

For gastropods, shell dry weight was used as a proxy for shell armor rather than shell lip thickness, because it was difficult to locate consistent measurement sites on the shell margins of all species. For each gastropod, tissue was loosened from the shell by boiling thawed individuals for 3 to $5 \mathrm{~min}$ in water in a microwave oven. Tissue was removed using a probe, and then shells were dried to a constant weight in a drying oven at $40^{\circ} \mathrm{C}$. Each specimen was measured for shell length (i.e. distance of the longest axis) and shell height (maximum distance of the dorso-ventral axis) for the snails, and shell width (maximum distance perpendicular to the longest axis) for the limpet, using digital calipers $( \pm 0.01 \mathrm{~mm})$. Each dried shell was weighed on a Mettler PG503 balance $( \pm 0.001 \mathrm{~g})$.

Feeding performance experiment. To test for geographic differences in feeding performance, a size

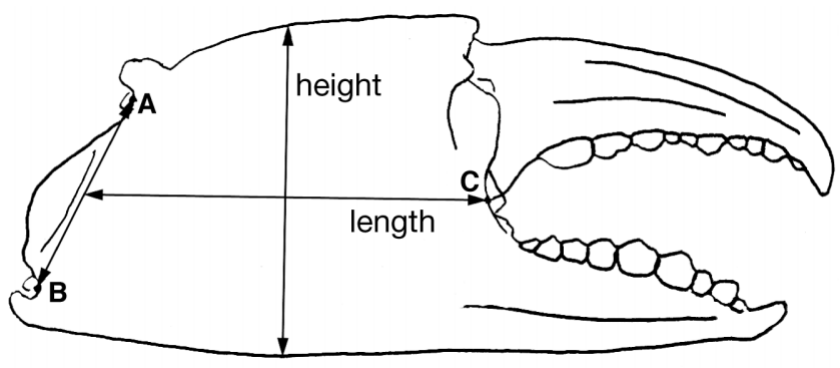

Fig. 1. Carcinus maenas. Diagram of outer face of right (crusher) claw. Manus height and length were calculated from landmark points A to $\mathrm{C}$ on the digitized outline of claw. Manus depth was measured with digital calipers $( \pm 0.01 \mathrm{~mm})$ as maximum dimension of manus perpendicular to drawing 
range of southern and northern male Carcinus maenas was presented with different sizes of southern or northern Littorina obtusata in laboratory feeding trials in October 1999. The objective was to determine the critical shell length at which a crab could no longer crush snails in a defined feeding period.

In September 1999, approximately 30 male Carcinus maenas were collected from each of 3 sites in Massachusetts (Pumphouse Beach, Nahant; Lobster Cove, Manchester-By-the-Sea; Back Beach, Rockport). All male C. maenas from Maine were collected from Carrying Place Cove, South Lubec, because only a few crabs were found at other sites. A size range of Littorina obtusata was also collected from Pumphouse Beach and Canoe Beach in Nahant, Massachusetts, and from the north side of West Quoddy Head, Maine ( 600 snails in each region). Crabs from each region were held in separate tanks supplied with running seawater at the Northeastern University Marine Science Center in Nahant and fed crushed mussels (Mytilus spp.) daily. Snails were held in large, meshsided containers filled with the brown algae Ascophyllum spp.

After 2 wk, 48 southern crabs and 42 northern crabs that spanned a size range (25 to $70 \mathrm{~mm} \mathrm{CW}$ ) were selected for the experiment. Only crabs that were right-handed, had both claws intact, and showed no signs of claw damage or regeneration (e.g. diminutive chelipeds, crusher on the left side) were used. Carapace width of each crab was measured and assigned to a treatment combination (see below) to ensure comparable size distributions. Crabs were placed singly in covered 21 polypropylene containers $(13 \times$ $13 \times 13 \mathrm{~cm}$, length $\times$ height $\times$ width). Each container received its own supply of unfiltered, ambient $\left(\sim 13^{\circ} \mathrm{C}\right)$, running seawater and was aerated by a single air stone. Containers were held in 2 seawater tables and allotted in such a way that crabs from each treatment combination were represented equally and arranged haphazardly in each table. Crabs were starved for $3 \mathrm{~d}$ prior to initiation of the experiment. Snails from each region were sorted into 3 overlapping size intervals (shell lengths 3-9, 6-12, 9-15 mm) before the experiment and these groups were held separately.

The experimental design consisted of 4 treatment combinations: southern crabs $(\mathrm{n}=24)$ offered southern snails; southern crabs ( $\mathrm{n}=24$ ) offered northern snails; northern crabs $(n=21)$ offered northern snails; and northern crabs $(n=21)$ offered southern snails. To determine the critical shell length of snails that each crab could crush, 3 feeding trials were conducted between 15 and 22 October 1999. For each crab in each trial, 2 smaller and 2 larger snails from one of the size intervals were selected, each snail's shell length
$( \pm 0.01 \mathrm{~mm})$ was measured with digital calipers, and then all 4 snails were introduced simultaneously into the container. Direct measurement of each shell length allowed me to assess the fate of individual snails after each trial and to determine the critical shell length more precisely.

In the first feeding trial, crabs $<39 \mathrm{~mm}$ in carapace width each received snails between 3 and $9 \mathrm{~mm}$ in shell length (SL); crabs 40 to $49 \mathrm{~mm}$ in CW received snails 6 to $12 \mathrm{~mm}$ in $\mathrm{SL}$; and crabs $>50 \mathrm{~mm}$ in $\mathrm{CW}$ received snails 9 to $15 \mathrm{~mm}$ in SL. All containers were checked after $24 \mathrm{~h}$. Each snail was scored as alive or dead. In addition, each shell was scored as undamaged, chipped along the shell lip, or crushed. The latter 2 categories provided evidence of unsuccessful and successful crushing attempts, respectively, by crabs. All snails or shell fragments were then removed.

A second feeding trial was begun immediately using the same crabs and new snails. The size interval of snails offered to a crab in the second trial depended on which size snails it had crushed in the first trial. If no snails were crushed in the first trial, was offered the crab 4 snails from the next smaller size interval for the second trial. If either of the 2 smaller snails in the size interval were crushed, then the same size interval was tested again in the second trial. If either of the 2 larger snails in a size interval were crushed, then 4 snails from the next larger size interval were offered to the crab. As before, the condition of all snails and their shells was recorded after $24 \mathrm{~h}$ and all snails and shell fragments were removed.

A third feeding trial was conducted $72 \mathrm{~h}$ later with a subset of crabs to clarify instances in which predation outcomes were uncertain. For example, on a few occasions shells showed no evidence of chipping or crushing in a trial. In other instances, I wished to narrow the observed size interval between crushed and chipped shells. For each crab, the critical shell length was calculated as the average between the largest size snail shell crushed in the trials and the next larger size that was chipped but not crushed. Crab-snail combinations were not included in analyses if: (1) the crab molted during or shortly after the experiment, (2) the crab crushed the maximum snail size available or (3) the difference between the largest shell crushed and the next larger size damaged exceeded $1.3 \mathrm{~mm}$ SL.

After the feeding trials had been completed, the manus height (maximum dimension) of the crusher claws of crabs used in the experiment was measured using digital calipers. Extra snails from each region were measured for shell-lip thickness (using digital calipers) and shell dry weight (as described earlier).

Statistical analyses. Claw dimensions: Prior to analysis, all morphometric data for crabs collected in 
the geographic survey were $\log _{10}$ transformed. Statistical analyses were performed using JMP 4.04 software (SAS Institute 2000). To compare overall claw size between regions, principal components from the correlation matrix for the variables manus height, manus length, and manus depth were generated. For each claw type (crusher, cutter), loadings on PC1 were compared between southern and northern regions (fixed effect) using a nested analysis of covariance (ANCOVA). Sites were nested within region and treated as a random effect. Carapace width, which varied isometrically with carapace length, served as the covariate. Models were run using both the expected mean squares (EMS) and the residual maximum likelihood (REML) options in JMP 4.04. Because qualitative outcomes were consistent with either method, only the EMS results were reported. The fixed-effects test in the EMS method used a synthetic denominator (see footnote to Table 2) and its degrees of freedom were calculated using Satterthwaite's method (SAS Institute 2000). Slopes were tested for homogeneity (Sokal \& Rohlf 1981).

To determine whether particular claw dimensions varied geographically, separate analysis of variance (ANOVA) tests of manus height, length and depth were conducted for the crusher and cutter claws. To remove confounding effects of body size, each manus dimension of the crusher or cutter was regressed against carapace width for individuals from all sites. These regressions were performed separately for each sex, because male claws exhibited greater positive allometry than females (see Table 1). The manus dimension for each crusher or cutter claw was then expressed as a deviation (residual) from the appropriate sex-specific regression. For each claw type, the residuals for a given manus dimension were compared between regions using a 2-factor (region, sex) nested ANOVA. Sites were treated as a random effect nested within each region, and the ANOVAs were analyzed using the EMS option as before. For interpretability, back-transformed means of manus dimensions, adjusted for carapace width, were presented in all figures.

Prey dimensions: To examine geographic patterns in the shell armor of gastropods, separate ANOVA tests were conducted for each species. To remove confounding effects of body size, residuals were generated by regressing $\log _{10}$ shell dry weight against $\log _{10}$ shell length for individuals from all sites. Residuals for shell weight were compared between regions for each species using a nested ANOVA. Sites were treated as a random effect nested within each region. Sizeadjusted means were back-transformed for presentation in the figures. In contrast to the other gastropods, Littorina obtusata had 2 distinct shell forms. The less common high-spired forms were excluded from the ANOVA analysis to restrict comparisons to snails with similar shell shape (i.e. low spires).

Performance experiment: To examine geographic differences in crushing performance, critical shell lengths of snails were compared using a 2-factor (source of crab population, source of snail population) ANCOVA. Manus heights of southern and northern crabs from the experiment were also compared using ANCOVA. Because experimental crabs were males and almost all were post-pubertal, manus height varied linearly with the covariate, carapace width. As a consequence, log-transformation was unnecessary, and analyses were conducted on untransformed data. Shell-lip thickness and shell dry weight of extra southern and northern snails were compared using separate ANCOVA models. Shell length was the covariate in both instances. Analysis was conducted on untransformed data for shell lip thickness. Shell dry weights were transformed to the cube root prior to analysis to improve linearity with the covariate.

\section{RESULTS}

\section{Crab sizes and sex ratios}

The mean carapace widths of Carcinus maenas used in analyses did not differ between southern and northern regions (1-way nested ANOVA, $F=2.09$, df $=1$, $4.1, \mathrm{p}=0.22)$ or among sites within regions $(F=1.46$, $\mathrm{df}=4,141, \mathrm{p}=0.22$ ). The mean $\mathrm{CW} \pm 1 \mathrm{SE}$ of $C$. maenas across all sites in the southern region was $31.9 \pm$ $1.38 \mathrm{~mm}$ (range 14.8 to $61.5 \mathrm{~mm} ; \mathrm{n}=80$ ). In the northern region, the mean $\mathrm{CW} \pm 1 \mathrm{SE}$ was $35.3 \pm 1.47 \mathrm{~mm}$ (range, 16.4 to $50.1 \mathrm{~mm} ; \mathrm{n}=67$ ). Sex ratios differed significantly between the southern (43 males:37 females) and northern (18 males:49 females) samples (2-way contingency analysis, $G^{2}=11.08, \mathrm{df}=1,145, \mathrm{p}=$ 0.0009).

\section{Sexual dimorphism and laterality in claw size}

Carcinus maenas are sexually dimorphic as adults, and in my collections all 3 manus dimensions differed significantly between sexes as body size increased (i.e. slopes were heterogeneous, 1-way ANCOVAs, p $\leq$ 0.005). Male claws showed positive allometry relative to $\mathrm{CW}$, while females tended toward isometry (Table 1). C. maenas are also heterochelous. Crusher claws were larger than cutter claws for all dimensions (1-way ANCOVAs, p < 0.0001), and males showed a greater degree of handedness than females (Table 1). 
Table 1. Carcinus maenas. Regression analyses of claw dimension versus carapace width (CW) for crusher and cutter claws of male (M) and female (F) crabs collected from southern and northern sites in the Gulf of Maine. Claw dimensions were manus height, manus length, and manus depth. $\log _{10}$ claw dimension $(Y$, in $\mathrm{mm})$ was regressed against $\log _{10} \mathrm{crab} \mathrm{CW}(X$, in $\mathrm{mm})$ for each claw type and sex across all 6 sites combined $\pm 1 \mathrm{SE}$ of slope term is given in parentheses. Range of CWs for males was $14.8-53.9$ mm $(n=61)$, and for females $16.4-61.5 \mathrm{~mm}(n=86) . R^{2}$ and Significance of regression equation are $\operatorname{shown}\left({ }^{* * *} \mathrm{p}<0.001\right)$

\begin{tabular}{|cccccc}
\hline Dimension & $\begin{array}{c}\text { Crusher } \\
\text { Regression }\end{array}$ & $\mathrm{R}^{2}$ & $\begin{array}{c}\text { Cutter } \\
\text { Regression }\end{array}$ \\
\hline $\begin{array}{c}\text { Manus height } \\
\text { M }\end{array}$ & $\log Y=1.132( \pm 0.023) \log X-0.821$ & $0.977^{* * *}$ & $\log Y=1.092( \pm 0.018) \log X-0.850$ & $0.984^{* * *}$ \\
F & $\log Y=0.988( \pm 0.021) \log X-0.656$ & $0.964^{* * *}$ & $\log Y=1.033( \pm 0.012) \log X-0.784$ & $0.989^{* * *}$ \\
$\begin{array}{c}\text { Manus length } \\
\text { M }\end{array}$ & $\log Y=1.142( \pm 0.018) \log X-0.749$ & $0.985^{* * *}$ & $\log Y=1.125( \pm 0.016) \log X-0.756$ & $0.988^{* * *}$ \\
F & $\log Y=0.992( \pm 0.014) \log X-0.563$ & $0.983^{* * *}$ & $\log Y=1.011( \pm 0.009) \log X-0.612$ & $0.993^{* * *}$ \\
$\begin{array}{c}\text { Manus depth } \\
\text { M }\end{array}$ & $\log Y=1.137( \pm 0.020) \log X-1.001$ & $0.983^{* * *}$ & $\log Y=1.095( \pm 0.020) \log X-1.022$ & $0.980^{* * *}$ \\
F & $\log Y=0.966( \pm 0.018) \log X-0.796$ & $0.971^{* * *}$ & $\log Y=0.997( \pm 0.012) \log X-0.903$ & $0.987^{* * *}$ \\
\hline
\end{tabular}

\section{Geographic variation in claw morphology}

Principal components analysis revealed significant geographic variation in claw size in the Gulf of Maine. The first principal component (PC1) explained 99.75\% of the variance in both crusher and cutter claw dimensions and served as a measure of overall claw size in each case. Crabs collected from southern sites had relatively larger crusher claws (PC1 adjusted for carapace width) than crabs from northern sites (1-way nested ANCOVA, $p=0.034$ ) (Table 2). In contrast, cutter claw size did not differ between regions (1-way nested ANCOVA, $p=0.246$ ). Significant size variation, however, was detected among sites within regions for both crusher and cutter claws ( $p=0.002)$ (Table 2).

Manus height contributed more toward the regional difference in crusher claw size than manus length or depth. The relative manus height of crusher claws was significantly greater $(6.5 \%)$ in southern than in northern crabs (2-way nested ANOVA; region effect, $F=9.85$; df $=1,4.2 ; \mathrm{p}=0.032$ ) (Fig. 2A). Manus length and manus depth of crusher claws showed a similar trend, but differences were not statistically significant (Fig. 2B,C). All 3 crusher claw dimensions varied significantly among sites within regions, and again, manus height exhibited the greatest effect (Fig. 2A-C). The average deviation in crusher manus height for female crabs was greater than for males (sex effect; $F=5.47 ; \mathrm{df}=1,139 ; \mathrm{p}=0.021$ ), and this trend was consistent between regions (region $\times$ sex interaction, $F=0.45, \mathrm{df}=1,139, \mathrm{p}=0.50$ ) (Fig. 2A; only significance levels shown). In absolute terms, crusher manus heights of females (back-transformed mean $=6.77 \mathrm{~mm}$, $\log \mathrm{SE}=0.014)$ were still smaller than those of males (back-transformed mean $=7.45 \mathrm{~mm}$, $\log \mathrm{SE}=0.022$ ).

In contrast to results for the crusher claw, I observed no regional differences in manus dimensions for cutter claws (2-way nested ANOVAs, Fig. 2D-F). The only significant spatial variation detected was among sites within regions for relative manus height of the cutter claw (Fig. 2D). Manus length and manus depth of cutter claws showed similar tendencies, but differences among sites were not statistically significant (Fig. 2E, F). None of the relative cutter claw dimensions differed between sexes $(p \geq 0.273)$.

\section{Geographic variation in shell thickness and size}

Size-adjusted shell dry weights did not differ significantly between regions for any of the 4 species of gastropod molluscs collected (1-way nested ANOVAs on residuals, region effect, $p \geq 0.111$ ) (Fig. 3A,B,D). Signifi-

Table 2. Carcinus maenas. Comparison of first principal components (PC1) of crusher and cutter claws between regions (southern $[\mathrm{S}]$ vs northern $[\mathrm{N}])$. PC1 reflects overall claw size (components = $\log _{10}$ manus height, length, and depth). Sites were nested within region and $\log _{10}$ carapace width (CW) was covariate. Contrast (Cont.) indicates direction of the relationship. ns: not significant

\begin{tabular}{|c|c|c|c|c|c|}
\hline Source & df & MS & $F$ & $\mathrm{p}$ & Cont. \\
\hline \multicolumn{6}{|c|}{ Crusher size: PC1 } \\
\hline Region & 1 & 4.716 & $9.82^{\mathrm{a}}$ & 0.034 & \multirow[t]{4}{*}{$\mathrm{S}>\mathrm{N}$} \\
\hline Site (Region) & 4 & 0.496 & $4.66^{\mathrm{b}}$ & 0.002 & \\
\hline Log CW & 1 & 396.540 & $3722.97^{\mathrm{b}}$ & $<0.001$ & \\
\hline Residual & 140 & 0.106 & & & \\
\hline \multicolumn{6}{|c|}{ Cutter size: PC1 } \\
\hline Region & 1 & 0.439 & $1.84^{\mathrm{a}}$ & 0.246 & \multirow[t]{4}{*}{ ns } \\
\hline Site (Region) & 4 & 0.247 & $4.61^{\mathrm{b}}$ & 0.002 & \\
\hline Log CW & 1 & 397.818 & $7428.52^{\mathrm{b}}$ & $<0.001$ & \\
\hline Residual & 140 & 0.054 & & & \\
\hline \multicolumn{6}{|c|}{$\begin{array}{l}{ }^{a} \text { Error, synthetic denominator calculated from variance com- } \\
\text { ponents of random effect and residual (SAS Institute 2000) } \\
{ }^{b} \text { Error, calculated from residual }\end{array}$} \\
\hline
\end{tabular}




\section{Crusher}
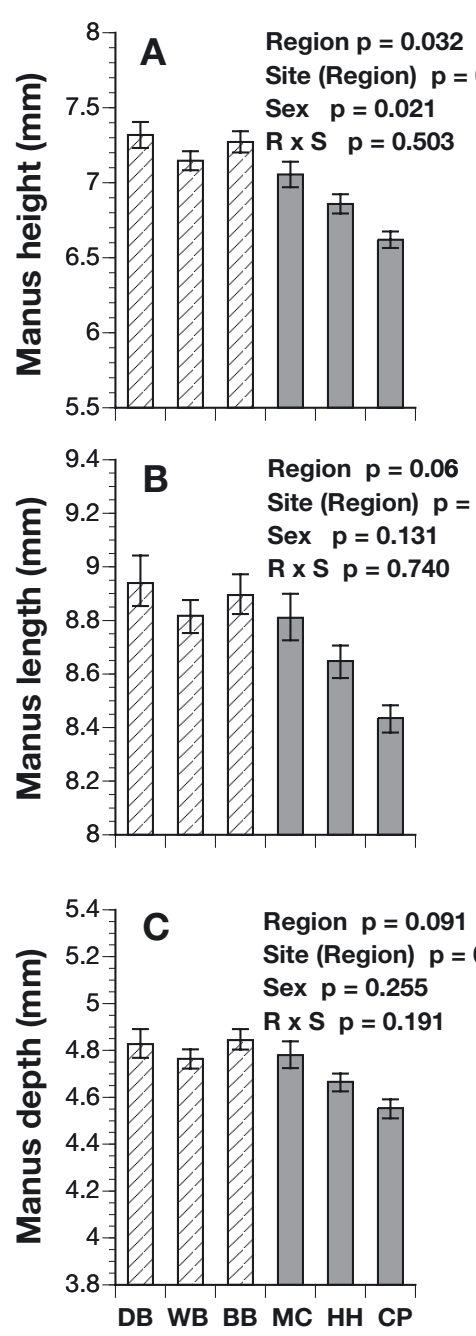

Cutter
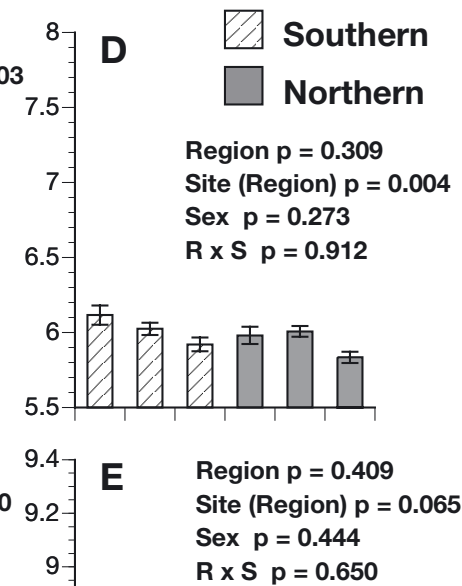

$\mathrm{R} \times \mathrm{S} p=0.650$
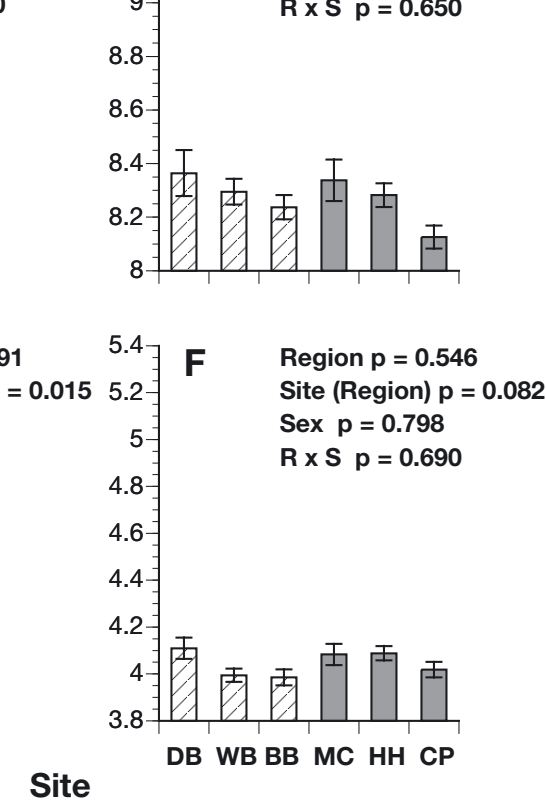

Fig. 2. Carcinus maenas. Comparisons of mean $( \pm 1$ SE) manus height, length and depth between regions (southern vs northern) and sites within regions in Gulf of Maine for crusher and cutter claws. Southern crabs were collected from 3 sites in Massachusetts (hatched bars): Dive Beach, (DB, $\mathrm{n}=$ 20 crabs), White Beach (WB, $\mathrm{n}=31$ ), and Back Beach (BB, $\mathrm{n}=29)$. Northern crabs were collected from 3 sites in Maine (shaded bars): Money Cove $(\mathrm{MC}, \mathrm{n}=21$ crabs), Haycock Harbor $(\mathrm{HH}, \mathrm{n}=27)$, and Carrying Place Cove $(\mathrm{CP}, \mathrm{n}=19)$. Means for each manus dimension $(\mathrm{mm})$ were adjusted for carapace width and back-transformed for presentation. $\mathrm{p}$-values indicate significance levels from 2-way nested ANOVAs comparing residuals of claw dimensions for region, sites within region, sex, and interaction of region by $\operatorname{sex}(\mathrm{R} \times \mathrm{S})$

cant variation in relative shell dry weight was observed among sites within regions for Littorina obtusata (Fig. 3A), Nucella lapillus (Fig. 3C) and Tectura testudinalis (Fig. 3D), but not for $L$. littorea (Fig. 3B).

At all sites, Littorina obtusata was the smallest and most common of the potential prey species (mean shell length $\pm 1 \mathrm{SE}=10.6 \pm 0.12 \mathrm{~mm}$; range $=3.3$ to $15.0 \mathrm{~mm}$; $\mathrm{n}=426$ ) (see inset in Fig. 3A). Mean shell lengths $( \pm 1 \mathrm{SE})$ were greater for L. littorea $\left(15.4 \pm 0.34 \mathrm{~mm}_{\text {; }}\right.$ range $=3.4$ to $27.5 \mathrm{~mm}$; $\mathrm{n}=276)$, Nucella lapillus $(23.1 \pm 0.57 \mathrm{~mm}$; range $=13.3$ to $34.7 \mathrm{~mm}_{i} \mathrm{n}=91$ ), and Tectura testudinalis $(14.0 \pm 0.35 \mathrm{~mm}$; range $=$ 7.3 to $22.2 \mathrm{~mm} ; \mathrm{n}=101$ ) (insets in Fig. 3B-D). The frequency of the $2 L$. obtusata shell forms differed between regions (2-way contingency analysis, $G^{2}=$ 71.64, $\mathrm{df}=1,424, \mathrm{p}<0.0001$ ). Low-spired forms occurred in Maine $(\mathrm{n}=184)$ and Massachusetts $(\mathrm{n}=185)$, but high-spired ( $n=57$ ) forms were found only in Maine.

\section{Crushing performance}

In the feeding experiment, southern Carcinus maenas were able to crush Littorina obtusata snails of larger critical shell lengths than were northern crabs (2-way ANCOVA, Crab population effect, $\mathrm{p}=$ 0.0078; Table 3 \& Fig. 4). Familiarity with the prey population did not seem to influence crab performance, because southern crabs outperformed northern crabs regardless of which snail population they were fed (crab $\times$ snail interaction, $\mathrm{p}=0.96$, Table 3 ; Fig. 4). Overall, southern snails attained a size refuge from crushing at a smaller critical shell length than did northern snails (Snail population, $\mathrm{p}<0.0001$, Table 3, Fig. 4). As expected, larger crabs were able to crush larger shells in all treatment combinations (regressions in Table 3), although the pairings did not all scale similarly (slope coefficients $=0.757$ to 1.524 ) .

Southern and northern crabs differed significantly in crusher manus height (1-way ANCOVA, $F=32.1 ; \mathrm{df}=1,82 ; \mathrm{p}<$ 0.0001) (Table 4 \& Fig. 5A). The sizeadjusted mean manus height of crusher claws of southern crabs $(12.62 \mathrm{~mm} \pm 0.14)$ was $9.4 \%$ greater than that of northern crabs (11.54 $\mathrm{mm} \pm 0.13$ ). Mean values for these manus heights are not directly comparable to those from the geographic survey (Fig. 2A) because (1) the greatest distance across the manus height was assessed in the experimental crabs (vs height at the midpoint along the manus length in survey crabs) and (2) all experimental crabs were male (vs male and female crabs in the survey).

Southern and northern Littorina obtusata collected from the same populations as those used in the experi- 


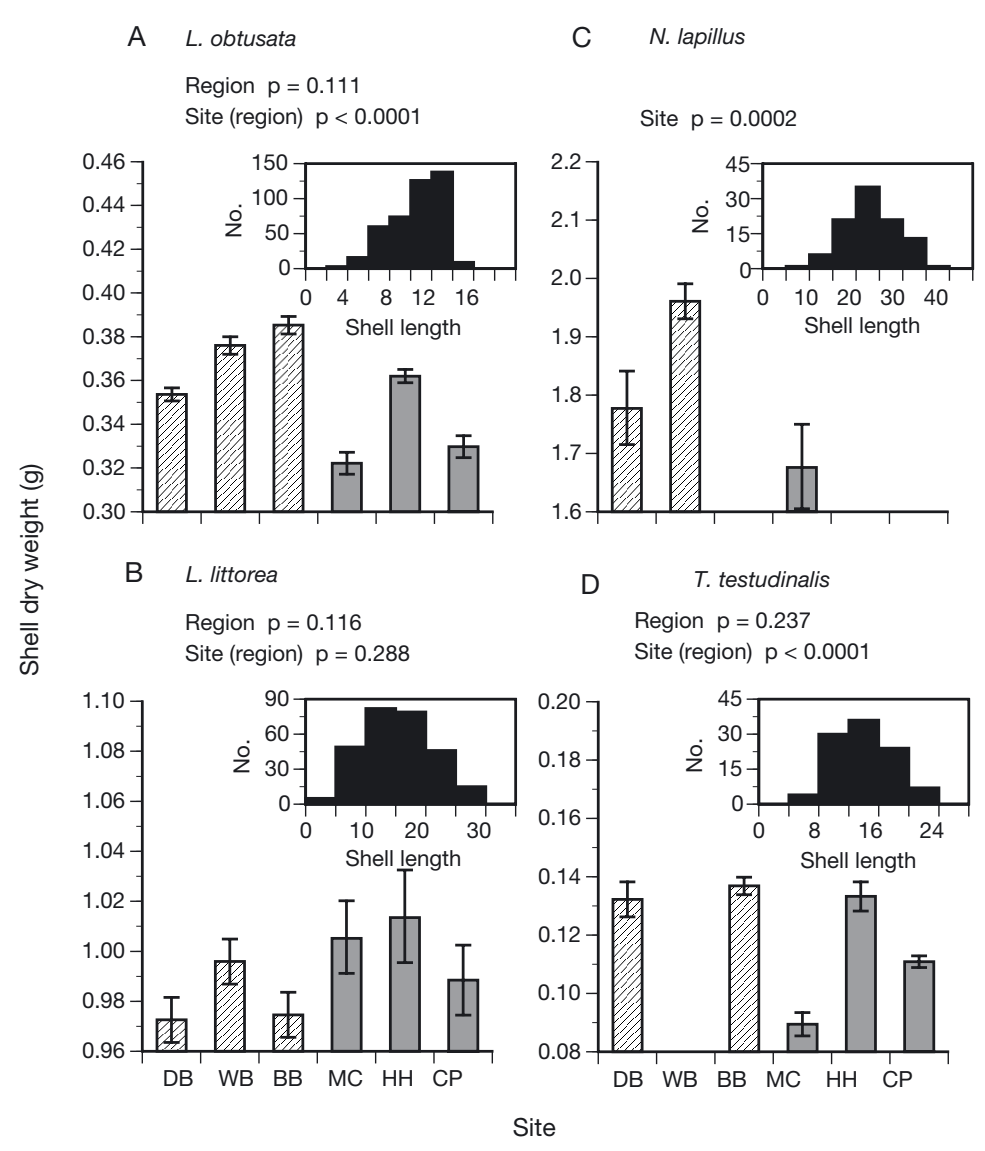

Fig. 3. Littorina obtusata, L. littorea, Nucella lapillus, and Tectura testudinalis. Comparisons of mean $( \pm 1 \mathrm{SE})$ shell dry weight between regions and sites within regions. Hatched bars represent southern sites; shaded bars northern sites. Mean shell dry weights $(\mathrm{g})$ were adjusted for shell length and back-transformed for presentation. $p$-values indicate significance levels from 1-way nested ANOVAs comparing residuals of shell dry weights for region and sites within region. $N$. lapillus were found at only 1 northern site; hence, only sites were compared. Insets: size-frequency diagrams illustrating frequency of individuals (No.) versus shell length $(\mathrm{mm})$ for each species for all sites combined. Site abbreviations as in Fig. 2 ments differed significantly in size-adjusted shell-lip thickness and shell dry weight (Table 4 \& Fig. 5B,C). Southern snails had thicker shell lips (1.36 $\mathrm{mm} \pm 0.02 \mathrm{SE}$ ) and weighed more $\left(0.260 \mathrm{~g} \pm 1 \mathrm{SE}^{1 / 3}, 0.004\right)$ per unit shell length than did northern snails (lip thickness, $1.13 \mathrm{~mm} \pm 0.02 \mathrm{SE}_{\text {; }}$ shell dry weight $0.206 \mathrm{~g} \pm$ $1 \mathrm{SE}^{1 / 3}, 0.004$, respectively). Average regional differences were $20.4 \%$ in lip thickness and $26.2 \%$ in shell weight. It should be noted that northern snails used in the performance experiment were collected from a site that was almost devoid of Carcinus maenas; whereas, those in the geographic survey were collected from sites where C. maenas were found.

\section{DISCUSSION}

\section{Biogeographical patterns in claw size and shell defense}

Claw sizes of the introduced crab Carcinus maenas have diverged in the Gulf of Maine following expansion of the species' range over the last century. Differences in claw size were limited to the crusher claw and were found in both sexes, which strongly suggests that the polymorphism is trophic in nature. Although decapod crustaceans use their claws for functions besides foraging (e.g. defense, resource acquisition, agonistic interactions), nontrophic considerations would most probably affect both crusher and cutter claws equally (e.g. water temperature) or be limited to 1 sex (e.g. males competing for mates). To my knowledge, this study is the first to document trophic polymorphism in an invasive marine

Table 3. Carcinus maenas and Littorina obtusata. Regression analyses and results of 2-way analysis of covariance (ANCOVA) comparing critical shell lengths of snails from the northern $\left(S_{N}\right)$ or southern $\left(S_{S}\right)$ regions offered to crabs from the northern $\left(C_{N}\right)$ or southern $\left(\mathrm{C}_{\mathrm{S}}\right)$ regions. Critical shell length was calculated as the midpoint between the shell lengths of the largest shell crushed and the next larger shell damaged, but not crushed, for each crab. Regression analyses were performed on log ${ }_{10^{-}}$ transformed data. The log critical shell length $(Y$, in $\mathrm{mm})$ was regressed against log crab carapace width $(X$, in mm) for each experimental pairing of crab $\times$ snail populations. $\pm 1 \mathrm{SE}$ of the slope term is given in parentheses. $\mathrm{R}^{2}$ and significance of regression equation are shown. ANCOVA analysis was conducted on untransformed data. Crab and snail populations were treated as fixed effects and crab carapace width as the covariate in the ANCOVA. ${ }^{* * *} \mathrm{p}<0.001$

\begin{tabular}{|c|c|c|c|c|c|c|c|}
\hline Pairing & $\begin{array}{c}\text { Regression } \\
\text { equation }\end{array}$ & $\mathrm{R}^{2}$ & Source & df & $\begin{array}{c}\text { ANCOVA } \\
\text { MS }\end{array}$ & $F$ & $\mathrm{p}$ \\
\hline $\mathrm{S}_{\mathrm{S}}$ vs $\mathrm{C}_{\mathrm{S}}$ & $\log Y=1.524( \pm 0.274) \log X-1.548$ & $0.61^{* * *}$ & Carapace width & 1 & 215.741 & 108.924 & $<0.0001$ \\
\hline $\mathrm{S}_{\mathrm{S}}$ vs $\mathrm{C}_{\mathrm{N}}$ & $\log Y=1.023( \pm 0.158) \log X-0.773$ & $0.76^{* * *}$ & Crab population & 1 & 14.889 & 7.517 & 0.0078 \\
\hline $\mathrm{S}_{\mathrm{N}}$ vs $\mathrm{C}_{\mathrm{S}}$ & $\log Y=0.810( \pm 0.158) \log X-0.291$ & $0.59^{* * *}$ & Snail population & 1 & 60.409 & 30.500 & $<0.0001$ \\
\hline \multirow[t]{2}{*}{$\mathrm{S}_{\mathrm{N}}$ vs $\mathrm{C}_{\mathrm{N}}$} & $\log Y=0.757( \pm 0.149) \log X-0.249$ & $0.66^{* * *}$ & Crab $\times$ snail & 1 & 0.005 & 0.003 & 0.9597 \\
\hline & & & Error & 67 & 1.981 & & \\
\hline
\end{tabular}


predator, and one of only a few examples reported for natural populations of an invertebrate.

Diet-dependent changes in claw morphology should reflect spatial variation in the relative amount and breakage resistance of hard-shelled prey. For a number of reasons, the smooth periwinkle Littorina obtusata was the species most likely to influence the claw form of green crabs. First, L. obtusata was the most common of the 4 gastropod species at each of the 6 locations studied, and green crabs are opportunistic feeders (Behrens Yamada 2001). Second, larger Carcinus maenas prefer L. obtustata over other common rocky intertidal species (Rangeley \& Thomas 1987): crabs over $40 \mathrm{~mm}$ CW consumed significantly more L. obtusata than other gastropods (L. littorea, Nucella lapillus) or barnacles (Semibalanus balanoides). Third, L. obtusata were the only prey whose populations fell entirely within a size range that was vulnerable to crushing by C. maenas (insets in Fig. 3). For example, green crabs were able to break the entire size range ( 3 to $14 \mathrm{~mm} \mathrm{SL}$ ) of L. obtusata offered in my foraging experiment. Other studies have shown that attack success rates in green crabs decline rapidly when shell heights are greater than $10 \mathrm{~mm}$ in littorine snails (Elner \& Raffaelli 1980) or $14 \mathrm{~mm}$ in the dogwhelk N. lapillus (Hughes \& Elner 1979). The majority of L. littorea, $N$. lapillus, and Tectura testudinalis in my survey exceeded these sizes; consequently, the shell characteristics of these larger individuals should have little influence on green crab claw morphology. Finally, bivalves, which are often important prey for $C$. maenas (Ropes 1968, Elner 1981, Grosholz et al. 2000), were not abundant at the sites studied here.

Significantly, geographic variation in claw size in the Gulf of Maine corresponded with a latitudinal cline in breakage resistance of Littorina obtusata. Several studies have shown that smooth periwinkle populations in the southern Gulf of Maine are thicker-shelled than those in the north (Seeley 1986, Trussell 1996, 2000, Trussell \& Smith 2000). My survey detected a statistically non-significant trend in the same direction for

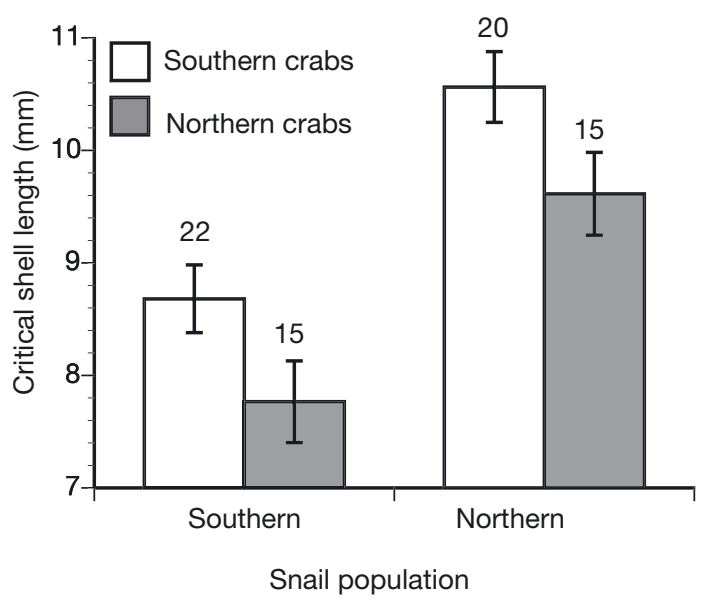

Fig. 4. Carcinus maenas and Littorina obtusata. Comparison of mean $( \pm 1 \mathrm{SE})$ critical shell length of southern and northern snails offered to southern or northern crabs in the feeding performance experiment. Mean critical shell lengths of snails were adjusted for predator size (crab carapace width, in $\mathrm{mm}$ ) using ANCOVA. Sample sizes (number of containers with a crab and snail prey) are given above each bar. See Table 3 for summary of statistical analyses

L. obtusata, but natural variation in shell thickness among sites, particularly in the north, probably obscured a regional effect (Fig. 3A). In a survey of $25 \mathrm{~L}$. obtusata populations, Trussell (2000) also documented greater variation in shell lip thickness in northern populations in the Gulf of Maine, which may reflect a patchier distribution of predators there than in the south. Finally, I observed a higher incidence of highspired L. obtusata in Maine than in Massachusetts. Seeley (1986) reported a similar distribution and demonstrated experimentally that high-spired forms are more vulnerable to crushing than are low-spired forms.

Geographic differences in claw size had clear functional consequences; southern Carcinus maenas were able to crush larger periwinkles than northern crabs

Table 4. Carcinus maenas and Littorina obtusata. Regression analyses of crusher claw manus height of crabs used in the foraging experiment, and shell-lip thickness and shell dry weight of snails collected from southern sites and 1 northern site. Manus height $(Y$, in $\mathrm{mm})$ was regressed against crab carapace width, $\mathrm{CW}(X$, in $\mathrm{mm})$ for each site. Shell-lip thickness $(Y$, in $\mathrm{mm})$ or shell dry weight $^{1 / 3}(Y$, in $\mathrm{g})$ of snails were regressed against shell length $(X$, in $\mathrm{mm}) . \pm 1 \mathrm{SE}$ of slope term is given in parentheses. Range of CWs for southern crabs was 32.5 to $63.3 \mathrm{~mm}(\mathrm{n}=42)$; for northern crabs 25.4 to $70.0 \mathrm{~mm}(\mathrm{n}=30)$. Range of shell lengths for southern snails was 4.3 to $14.2 \mathrm{~mm}(\mathrm{n}=45)$; for northern snails, 4.3 to $14.0 \mathrm{~mm}(\mathrm{n}=46) . \mathrm{R}^{2}$ and significance of regression are shown

$$
\left({ }^{* * *} \mathrm{p}<0.001\right)
$$

\begin{tabular}{|c|c|c|c|c|}
\hline \multirow[t]{2}{*}{ Dimension } & \multicolumn{2}{|c|}{ Southern } & \multicolumn{2}{|c|}{ Northern } \\
\hline & Regression & $\mathrm{R}^{2}$ & Regression & $\mathrm{R}^{2}$ \\
\hline Manus height & $Y=0.417( \pm 0.018) X-5.423$ & $0.926^{* * *}$ & $Y=0.399( \pm 0.011) X-5.733$ & $0.971^{* * *}$ \\
\hline Lip thickness & $Y=0.126( \pm 0.006) X+0.113$ & $0.910^{* * *}$ & $Y=0.125( \pm 0.005) X-0.114$ & $0.940^{* * *}$ \\
\hline Shell dry weight & $Y^{1 / 3}=0.063( \pm 0.001) X+0.011$ & $0.988^{* * *}$ & $Y^{1 / 3}=0.066( \pm 0.001) X-0.064$ & $0.980^{* * *}$ \\
\hline
\end{tabular}



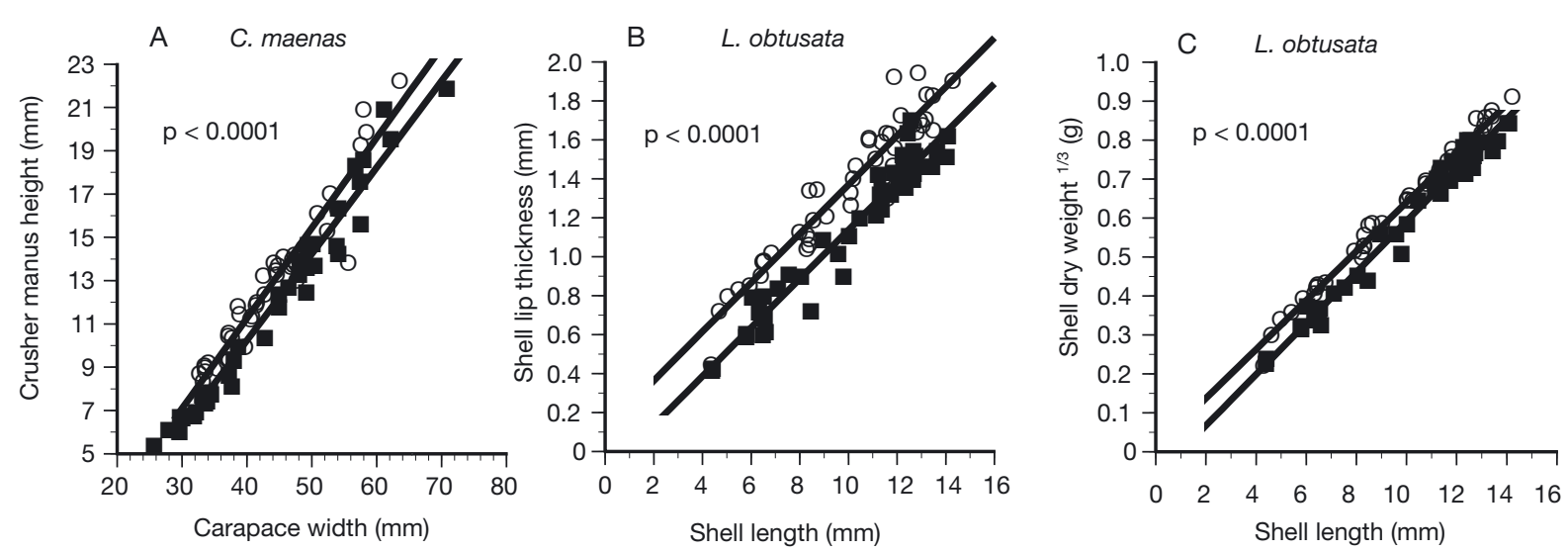

O Southern population

- Northern population

Fig. 5. Carcinus maenas and Littorina obtusata. Comparison in southern and northern populations of (A) crusher manus height versus carapace width of crabs in feeding performance experiment, (B) shell-lip thickness versus shell length and (C) shell dry weight ${ }^{1 / 3}$ versus shell length of snails collected from same sites as those used in experiment. $p$-values indicate significance levels from 1-way ANCOVAs comparing southern and northern populations of crabs or snails for relevant dimension. Covariate for crabs was carapace width, for snails shell length

in the foraging experiment. The difference in critical shell lengths (i.e. the upper size at which snails were no longer crushed) averaged $10.7 \%$ between the 2 crab treatments. The enhanced crushing performance of southern crabs was due to their relatively larger crusher claws. Manus height is a good indicator of claw strength within species (Lee 1993, Taylor 2001), and post-experiment analysis showed that the average manus height of the crusher claw of southern crabs was $9.4 \%$ greater than that of northern crabs. Claw strength in the crab populations co-varied with shell strength in the snail populations. Southern snails were able to resist being crushed at a much smaller average critical size $(8.22 \pm 0.24 \mathrm{~mm}$ SL) than northern snails $(10.10 \pm 0.24 \mathrm{~mm} \mathrm{SL})$. Analyses of size-adjusted shell-aperture lips and shell dry weights showed that the shell walls of snails in the southern treatment were significantly thicker than those in the northern treatment. Thicker-shelled molluscs withstand greater crushing forces than thinner-shelled individuals (Palmer 1985, Johannesson 1986).

Taken together, these data show a consistent, correlated geographic pattern in the morphology and performance of both predator and prey in the Gulf of Maine. Geographic differences in snail defenses have been reported previously; this study is the first to find corresponding differences in predator claw size. The patterns in Carcinus maenas appear robust, because differences in claw size were evident in each of $2 \mathrm{yr}$, and were expressed over a wide size range in both sexes. Previous attempts to correlate crab claw size and molluscan shell armor among crab species over inter-oceanic or broad latitudinal (temperate vs tropical) scales have yielded equivocal results (Vermeij 1977, Abele et al. 1981). In an intraspecific comparison, Blundon (1988) found no differences in claw size or closing force between stone crabs Menippe mercenaria from North Carolina and Florida. Similarly, Rebach \& Wower (1997) observed no consistent latitudinal trends in relative claw size of 2 cancrid species along the US Atlantic coast, although they detected significant among-site variation in claw size.

\section{Adaptive change in trophic structures}

Modifications of feeding structures are adaptive if they improve foraging effectiveness, are in response to a directional change in prey resistance, and are, to some extent, heritable (Travis 1994). The importance of claws as feeding devices and the benefits of larger claw size in crustaceans have been examined extensively. Given a choice, crabs select hard-shelled prey that are at or just below optimum size based on considerations of handling time, energy yield and other factors (e.g. Hughes \& Seed 1981, Juanes 1992, Mascaró \& Seed 2000). Although crabs utilize a range of handling techniques to gain access to the soft tissue of their prey (e.g. probing the aperture, peeling the outer whorl, prying valves, chipping valve edges), typically they first attempt to crush the shell outright (Hughes \& Elner 1979, Cunningham \& Hughes 1984). Increases in size, especially in manus height, result in claws with greater mechanical advantage, more muscle mass and a larger gape. Performance differences are evident within individuals when comparing 
crusher versus cutter claws (Warner et al. 1982, Schenk \& Wainwright 2001) or normal versus regenerating claws (Govind \& Blundon 1985, Brock \& Smith 1998), and between individuals as body size increases (e.g. Table 3). Crabs with larger, stronger claws should have a selective advantage, not only because these individuals have access to a wider range of prey types and sizes, but also because there is less risk of claw damage when attacking prey of any given size (Juanes \& Hartwick 1990, Juanes 1992, Juanes \& Smith 1995, Palmer et al. 1999, Taylor et al. 2000). Upper limits on claw size may be set by metabolic costs of maintenance or replacement or by allometric constraints associated with declining muscle stress as claw size increases (Taylor 2000, 2001). Despite the importance of claw size to fitness, the degree to which it is subject to directional selection is not known.

Claw size is capable of responding to environmental cues during development (Stein 1976, Govind 1987). By manipulating the diet of the homochelous crab Cancer productus, Smith \& Palmer (1994) showed that differential use influenced claw size in subsequent instars. Crabs reared on a hard diet of intact mussels developed claws with manus volumes $10-13 \%$ greater than those raised on a soft diet of experimentally opened mussels. If 1 claw was immobilized, the remaining functional claw became larger and stronger by the next instar. Brock \& Smith (1998) noted a similar compensatory response in the normal claw of $C$. productus individuals that were regenerating their other claw. Thus, the amount of diet-related exercise affects claw size both within and between individuals.

Diet-induced plasticity is the most likely explanation for observed variation in claw size of Carcinus maenas in the Gulf of Maine given the magnitude, specificity and speed of the response. First, the difference in manus volume between southern and northern crabs in the Gulf of Maine (12\%, author's unpubl. data) was remarkably consistent with the diet-induced differences observed by Smith and Palmer (1994). Second, significant geographic differences were found only in the crusher claw, which would be expected given that it, and not the cutter claw, is responsible for crushing prey. Third, geographic differentiation in claw size of C. maenas occurred quickly on an evolutionary time scale. While rapid directional selection cannot be ruled out, chances for genetic differentiation and local adaptation following the green crab invasion seem low. Green crab larvae disperse in the plankton for up to 50 d (Grosholz \& Ruiz 1995, Thresher et al. 2003), and circulation patterns in the Gulf of Maine (Conkling 1995) should distribute the larvae throughout the region.

\section{Biological invasions and ecological arms races}

Morphological changes in feeding structures allow predators to track variation in prey characteristics in time as well as space. Similarly, prey can reduce their vulnerability through morphological defensive responses. If these responses are reciprocal and the result of phenotypic plasticity, then an ecological arms race could result (Agrawal 2001, Kopp \& Tollrian 2003). For escalation to occur, ideally both predator and prey should produce a continuous range of phenotypes in response to cues from the other (Agrawal 2001).

The introduction of Carcinus maenas into the Gulf of Maine appears to have initiated such an arms race with at least 2 species of intertidal snails. In the century since the green crab's arrival, shell thickness in Littorina obtusata has increased by between 50 and $82 \%$ (Seeley 1986) and in Nucella lapillus by $12 \%$ (Vermeij 1982b). Although these shifts could reflect rapid evolution (Thompson 1998), predator-induced plasticity can also account for such a magnitude and speed of change. For example, in a reciprocal transplant field experiment, Trussell \& Smith (2000) demonstrated that L. obtusata could increase shell thickness by up to $47 \%$ in $90 \mathrm{~d}$ when exposed to C. maenas.

An ecological arms race would generate variation in predator and prey morphologies over a range of temporal and spatial scales. In the case of green crabs, as juveniles and adults migrate from deeper waters (or post-larvae settle) into shallow embayments in spring, their chemical cues should induce snails to lay down thicker shells. If background crabeffluent levels build up and remain sufficiently high (Trussell \& Smith 2000), then snails will become more resistant to breakage over the course of the growing season. In turn, crabs would be expected to develop larger and stronger claws in successive instars as they forage on better-defended (and bigger) prey. At sites where crabs are absent or few in numbers, phenotypic responses by snails would be less. On a regional scale, higher densities and a more uniform distribution of crabs in the southern Gulf of Maine should have elicited greater and more spatially consistent defensive responses in snail populations there than in the north. Colder temperatures at northern sites may also have contributed to thinner shells in the snails collected there (Trussell \& Smith 2000). Because claw sizes should increase no more than exercise demands, southern crabs would develop larger, stronger claws than their northern counterparts. The effects of temperature on cuticle strength, claw size, or muscle performance in crabs are not well known (Vermeij 1977, Blundon 1989) and deserve further study. 
By observing how non-native predators and native prey respond to each other over ecological time frames, we may better predict the consequences and geographic extent of an invasion. However, for most species introductions, we lack necessary information about the nature and strength of trophic interactions. Broadly distributed invaders are often assumed to be generalists (Lodge 1993), and malleability in trophic morphology may be another manifestation of this strategy. Carcinus maenas is a generalist in many respects (e.g. broad thermal and salinity tolerances) (Behrens Yamada 2001), and rapid modification of its claw size should promote its spread within and between regions and put native prey communities at greater risk, unless they can respond defensively. Larger relative claw size might also provide an invader with a competitive advantage over native species that have smaller claws or are less plastic.

Few other studies have linked trophic polymorphism in an invertebrate to geographic variation in a food resource (Carroll \& Boyd 1992, Carroll \& Dingle 1996). Trophic polymorphisms, however, may be as common in invertebrates as they are in vertebrates (Smith \& Skúlason 1996), given the growing list of diet-induced changes seen in various invertebrate taxa. Predatorinduced defenses are also widespread in both invertebrates and vertebrates (Tollrian \& Harvell 1999), which raises the possibility that reciprocal phenotypic responses are ubiquitous, but unrecognized. Whether ecophenotypic changes have long-term evolutionary consequences is not clear (Price et al. 2003), although the potential exists of genetic variation in plasticity. If so, then co-evolutionary arms races between many predators and prey may well have begun as shorterterm plastic responses between combatants.

Acknowledgements. I thank K. Aguilar, N. Dobroski, E. Thomas, and G. Trussell for their assistance in this study, and the Marine Science Center in Nahant for use of the facilities. The manuscript benefited from comments by F. Juanes, D. Lello, A. R. Palmer, G. J. Vermeij and an anonymous reviewer. Support for the project was provided by a grant from the National Science Foundation (Integrative Biology and Neuroscience-Ecological and Evolutionary Physiology 9817106).

\section{LITERATURE CITED}

Abele LG, Heck KL Jr, Simberloff DS, Vermeij GJ (1981) Biogeography of crab claw size: assumptions and a null hypothesis. Syst Zool 30:406-424

Abrams PA (2000) The evolution of predator-prey interactions: theory and evidence. Annu Rev Ecol Syst 31:79-105

Agrawal AA (2001) Phenotypic plasticity in the interactions and evolution of species. Science 294:321-326

Behrens Yamada S (2001) Global invader: the European green crab. Oregon State University, Corvallis, OR
Behrens Yamada S, Boulding EG (1998) Claw morphology, prey size selection and foraging efficiency in generalist and specialist shell-breaking crabs. J Exp Mar Biol Ecol 220:191-211

Bernays EA (1986) Diet-induced head allometry among foliage-chewing insects and its importance for graminivores. Science 231:495-497

Blundon JA (1988) Morphology and muscle stress of chelae of temperate and tropical stone crabs Menippe mercenaria. J Zool 215:663-673

Blundon JA (1989) Effects of temperature and thermal history on neuromuscular properties of two crustacean species. J Comp Physiol B 158:689-696

Boag PT, Grant PR (1981) Intense natural selection in a population of Darwin's finches (Geospizinae) in the Galapagos. Science 214:82-85

Brenchley GA, Carlton JT (1983) Competitive displacement of native mud snails by introduced periwinkles in the New England intertidal zone. Biol Bull (Woods Hole) 165:543-558

Brock RE, Smith LD (1998) Recovery of claw size and function following autotomy in Cancer productus (Decapoda: Brachyura). Biol Bull (Woods Hole) 194:53-62

Brodie ED III, Brodie ED Jr (1991) Evolutionary response of predators to dangerous prey: reduction of toxicity of newts and resistance of garter snakes in island populations. Evolution 45:221-224

Brodie ED III, Brodie ED Jr (1999) Predator-prey arms races. BioScience 49:557-568

Carroll SP, Boyd C (1992) Host race radiation in the soapberry bug: natural history, with the history. Evolution 46: 1052-1069

Carroll SP, Dingle H (1996) The biology of post-invasion events. Biol Conserv 78:207-214

Cohen AN, Carlton JT, Fountain MC (1995) Introduction, dispersal and potential impacts of the green crab Carcinus maenas in San Francisco Bay, California. Mar Biol 122: 225-237

Conkling PW (ed) (1995) From Cape Cod to the Bay of Fundy: an environmental atlas of the Gulf of Maine. MIT Press, Cambridge, MA

Crooks JA (1998) Habitat alteration and community-level effects of an exotic mussel, Musculista senhousia. Mar Ecol Prog Ser 162:137-152

Cunningham PN, Hughes RN (1984) Learning of predatory skills by shorecrabs Carcinus maenas feeding on mussels and dogwhelks. Mar Ecol Prog Ser 16:21-26

Dawkins R, Krebs JR (1979) Arms races between and within species. Proc Soc Lond Ser B 205:489-511

Day T, Pritchard J, Schluter D (1994) A comparison of two sticklebacks. Evolution 48:1723-1734

Elner RW (1978) The mechanics of predation by the shore crab, Carcinus maenas (L.), on the edible mussel, Mytilus edulis. Oecologia 36:333-344

Elner RW (1980) The influence of temperature, sex and chela size in the foraging strategy of the shore crab, Carcinus maenas (L.). Mar Behav Physiol 7:15-24

Elner RW (1981) Diet of green crab Carcinus maenas (L.) from Port Herbert, Southwestern Nova Scotia. J Shellfish Res 1: 89-94

Elner RW, Raffaelli DG (1980) Interactions between two marine snails Littorina rudis Maton and Littorina nigrolineata Gray, and a predator, Carcinus maenas (L.), and a parasite Microphallus similis Jägerskiold. J Exp Mar Biol Ecol 43:151-160

Geller JB, Walton ED, Grosholz ED, Ruiz GM (1997) Cryptic invasions of the crab Carcinus detected by molecular phylogeography. Mol Ecol 6:901-906 
Govind CK (1987) Muscle and muscle fiber type transformation in clawed crustaceans. Am Zool 27:1079-1098

Govind CK, Blundon JA (1985) Form and function of the asymmetric chelae in blue crabs with normal and reversed handedness. Biol Bull (Woods Hole) 168:321-331

Grosholz ED, Ruiz GM (1995) Spread and potential impact of the recently introduced European green crab, Carcinus maenas, in central California. Mar Biol 122:239-247

Grosholz ED, Ruiz GM (1996) Predicting the impact of introduced marine species: lessons from the multiple invasions of the European green crab Carcinus maenas. Biol Conserv 78:59-66

Grosholz ED, Ruiz GM, Dean CA, Shirley KA, Maron JL, Connors PG (2000) The impacts of a nonindigenous marine predator in a California bay. Ecology 81: 1206-1224

Hart MW, Strathmann RR (1994) Functional consequences of phenotypic plasticity in echinoid larvae. Biol Bull (Woods Hole) 186:291-299

Huey RB, Pianka ER (1981) Ecological consequences of foraging mode. Ecology 62:991-999

Hughes RN, Elner RW (1979) Tactics of a predator, Carcinus maenas, and morphological responses of the prey, Nucella lapillus. J Anim Ecol 48:65-78

Hughes RN, Seed R (1981) Size selection of mussels by the blue crab Callinectes sapidus: energy maximizer or time minimizer? Mar Ecol Prog Ser 6:83-89

Johannesson B (1986) Shell morphology of Littorina saxatilis Olivi: the relative importance of physical factors and predation. J Exp Mar Biol Ecol 102:183-195

Juanes F (1992) Why do decapod crustaceans prefer smallsized molluscan prey? Mar Ecol Prog Ser 87:239-249

Juanes F, Hartwick EB (1990) Prey size selection in Dungeness crabs: the effect of claw damage. Ecology 71:744-758

Juanes F, Smith LD (1995) The ecological consequences of limb damage and loss in decapod crustaceans: a review and prospects. J Exp Mar Biol Ecol 193:197-223

Kopp M, Tollrian R (2003) Reciprocal phenotypic plasticity in a predator-prey system: inducible offences against inducible defenses? Ecol Lett 6:742-748

Lee SY (1993) Chela height is an acceptable indicator of chela strength in Carcinus maenas (Linnaeus, 1758) (Decapoda, Brachyura). Crustaceana 65:115-116

Lemaitre R (1995) Charybdis hellerii (Milne Edwards, 1867), a nonindigenous portunid crab (Crustacea: Decapoda: Brachyura) discovered in the Indian River lagoon system of Florida. Proc Biol Soc Wash 108:643-648

Lima SL, Dill LM (1990) Behavioral decisions made under the risk of predation: a review and prospectus. Can J Zool 68: $619-640$

Lodge DM (1993) Biological invasions: lessons for ecology. Trends Ecol Evol 8:133-137

Mascaró M, Seed R (2000) Foraging behavior of Carcinus maenas (L.): species-selective predation among four bivalve prey. J Shellfish Res 19:293-300

Mittelbach GG, Ostenberg CW, Wainwright PC (1999) Variation in feeding morphology between pumpkinseed populations: phenotypic plasticity or evolution? Evol Ecol Res 1: 111-128

Padilla DK (1998) Inducible phenotypic plasticity of the radula in Lacuna (Gastropoda: Littorinidae). Veliger 41:201-204

Palmer AR (1985) Adaptive value of shell variation in Thais lamellosa: effect of thick shells on vulnerability to and preference by crabs. Veliger 27:349-356

Palmer AR, Taylor GM, Barton A (1999) Cuticle strength and size-dependence of safety factors in Cancer crab claws. Biol Bull (Woods Hole) 196:281-294
Pfennig DW, Murphy PJ (2002) How fluctuating competition and phenotypic plasticity mediate species divergence. Evolution 56:1217-1228

Preston SJ, Revie IC, Orr JF, Roberts D (1996) A comparison of strengths of gastropod shells with forces generated by potential crab predators. J Zool 238:181-193

Price TD, Qvarnström A, Irwin DE (2003) The role of phenotypic plasticity in driving genetic evolution. Proc R Soc Lond Ser B 270:1433-1440

Pyke GH (1984) Optimal foraging theory: a critical review. Annu Rev Ecol Syst15:523-575

Rangeley RW, Thomas MLH (1987) Predatory behaviour of juvenile shore crab Carcinus maenas (L.). J Exp Mar Biol Ecol 108:191-197

Rebach S, Wowor D (1997) Latitudinal variation of claw attributes in east coast cancrid crabs. J Crustac Biol 17:227-235

Reid DG, Mak YM (1999) Indirect evidence for ecophenotypic plasticity in radular dentition of Littoraria species (Gastropoda: Littorinidae). J Molluscan Stud 65:355-370

Ropes JW (1968) The feeding habits of the green crab Carcinus maenas (L.). Fish Bull 67:183-203

SAS Institute (2000) JMP statistics and graphics guide. Version 4, SAS Institute, Cary, NC

Scattergood LW (1952) The distribution of the green crab, Carcinides maenas (L.) in the northwestern Atlantic. Rep Fish Circ 8, Maine Department of Sea and Shore Fisheries, Augusta, GA

Schenk SC, Wainwright P (2001) Dimorphism and the functional basis of claw strength in six brachyuran crabs. J Zool 255:105-119

Seed R, Hughes RN (1995) Criteria for prey size-selection in molluscivorous crabs with contrasting claw morphologies. J Exp Mar Biol Ecol 193:177-195

Seeley RH (1986) Intense natural selection caused a rapid morphological transition in a living marine snail. Proc Natl Acad Sci USA 83:6897-6901

Skúlason S, Smith TB (1995) Resource polymorphisms in vertebrates. Trends Ecol Evol 10:366-370

Smith LD, Palmer A (1994) Effects of manipulated diet on size and performance of brachyuran crab claws. Science 254: $710-712$

Smith TB, Skúlason S (1996) Evolutionary significance of resource polymorphisms in fishes, amphibians and birds. Annu Rev Ecol Syst 27:111-133

Sokal RR, Rohlf FJ (1981) Biometry. The principles and practice of statistics in biological research, 2nd edn. WH Freeman, New York

Stein RA (1976) Sexual dimorphism in crayfish chelae: functional significance linked to reproductive activities. Can J Zool 54:220-227

Taylor GM (2000) Maximum force production: why are crabs so strong? Proc R Soc Lond Ser B 267:1475-1480

Taylor GM (2001) The evolution of armament strength: evidence for a constraint on the biting performance of claws of durophagous decapods. Evolution 55:550-560

Taylor GM, Palmer AR, Barton AC (2000) Variation in safety factors of claws within and among six species of Cancer crabs (Decapoda: Brachyura). Biol J Linn Soc 70:37-62

Thompson JN (1998) Rapid evolution as an ecological process. Trends Ecol Evol 13:329-332

Thresher R, Proctor C, Ruiz G, Gurney R, MacKinnon C, Walton W, Rodriguez L, Bax N (2003) Invasion dynamics of the European shore crab, Carcinus maenas, in Australia. Mar Biol 142:867-876

Tollrian R, Harvell CD (eds) (1999) The ecology and evolution of inducible defenses. Princeton University Press, Princeton, NJ 
Travis J (1994) Evaluating the adaptive role of morphological plasticity. In: Wainwright PC, Reilly SM (eds) Ecological morphology: integrative organismal biology. University of Chicago Press, Chicago, p 99-122

Trussell GC (1996) Phenotypic plasticity in an intertidal snail: the role of a common crab predator. Evolution 50:448-454

Trussell GC (2000) Phenotypic clines, plasticity, and morphological trade-offs in an intertidal snail. Evolution 54:151-166

Trussell GC, Smith LD (2000) Induced defenses in response to an invading crab predator: an explanation of historical and geographic phenotypic change. Proc Nat Acad Sci USA 97:2123-2127

Vermeij GJ (1977) Patterns in crab claw size: the geography of crushing. Syst Zool 26:138-151

Vermeij GJ (1978) Biogeography and adaptation: patterns of marine life. Harvard University Press, Cambridge, MA

Vermeij GJ (1982a) Environmental change and the evolutionary history of the periwinkle (Littorina littorea) in North America. Evolution 36:561-580

Vermeij GJ (1982b) Phenotypic evolution in a poorly dispersing snail after arrival of a predator. Nature 299:349-350

Vermeij GJ (1996) An agenda for invasion biology. Biol Conserv 78:3-9

Wainwright PC (1994) Functional morphology as a tool in ecological research. In: Wainwright PC, Reilly SM (eds) Eco-

Editorial responsibility: Roger Hughes (Contributing Editor), Bangor, UK logical morphology: integrative organismal biology. University of Chicago Press, Chicago, p 42-59

Wainwright PC, Osenberg CW, Mittelbach GG (1991) Trophic polymorphism in the pumpkinseed sunfish (Lepomis gibbosus Linnaeus): effects of environment on ontogeny. Funct Ecol 5:40-55

Walls SC, Belanger SS, Blaustein AR (1993) Morphological variation in a larval salamander: dietary induction of plasticity in head shape. Oecologia 96:162-168

Warner GF, Jones AR (1976) Leverage and muscle type in crab chelae. J Zool 180:57-68

Warner GF, Chapman D, Hawkey N, Waring DG (1982) Structure and function of the chelae and chela closer muscles of the shore crab Carcinus maenas (Crustacea: Brachyura). J Zool 196:431-438

Welch WR (1968) Changes in the abundance of the green crab, Carcinus maenas (L.), in relation to recent temperature changes. Fish Bull 67:337-345

West K, Cohen A, Baron M (1991) Morphology and behavior of crabs and gastropods from Lake Tanganyika, Africa: implications for lacustrine predator-prey coevolution. Evolution 45:589-607

Wimberger PH (1991) Plasticity of jaw and skull morphology in the neotropical cichlids Geophagus brasiliensis and $G$. steindachneri. Evolution 45:1545-1563

Submitted: December 19, 2003; Accepted: March 25, 2004

Proofs received from author(s): June 23, 2004 